\title{
Pynchon og tresserne
}

\author{
DAVID COWART
}

Diskussioner af den litteratur, der begyndte at dukke frem i pertoden umiddelbart efter 2. Verdenskrig, fremhæver ofte den post-Joyceske refleksivitet. Med Beckett som en slags stifinder og Nabokovsomen anden blev forfattere i stigende grad engageret $i$ en spørgen til deres medium - en sondering af sproget og dets epistemologiske akkreditiver. Disse akkreditiver var stort set ikke blevet undersøgt af de modernistiske forfattere, selv de der - som Eliot i "Bumt Norton" - erkendte og bekymrede sig om ords tilbøjeli_ghed til at svigte:

Words strain,

Crack and sometimes break, under the burden

Under the tension, slip, slide, perish,

Decay with imprecision, will not stay in place,

Will not stay still.

Modernisterne stræbte efter at udforske bevidsthed, tid og historie - netop de virkeligheder, der er mest modstandsdygtige over for sproglig repræsentation. Ikke desto mindre forblev sproget dog et erkendelsesredskab for dem, og Brian McHale har således karakteriseret det modernistiske projekt som epistemologisk i dets forudsætninger, midler og mål. I modsætning hertil synes postmodernisterne at være begyndt med en erkendelse af sprogets mimetiske og referentielle mangler - en opfattelse, der ifølge McHale ledte til en litterær kunst, som var mere interesseret i ontologi end epistemologi. Som John Hawkes engang bemærkede i et interview: „Jeg vil prøve at skabe en verden, ikke repræsentere den" (154). 
Men selvfølgelig forholder sagerne sig aldrig helt så enkelt. Det virkelige skift, som Lyotard argumenterer for i Viden og det postmoderne samfund, er mod repræsentationen af det stadigt mindre repræsenterbare. Modernisterne, siger han, søgte at repræsentere det urepræsenterbare; postmodernisterne søger at repræsentere det urepræsenterbare i selve repræsentationen. Dette er ikke ontologi, men en mere subtil epistemologi - en $b_{r y}$ dekamp med repræsentationens problematik. Så tidligt som The Real Life of Sebastian Knight (1941) fremmaner Nabokov således en Velasquez-agtig refleksivitet for at "illustrere" det selvreferentielle element i et imaginært litterært kunstværk: „Det er, som om en maler sagde: se, her vil jeg ikke vise dig et maleri af et landskab, men et maleri af forskellige måder hvorpå man kan male et bestemt landskab, og jeg håber, at deres harmoniske fusion vil åbenbare landskabet, som jeg ønsker du skal se det" (89). Nabokov gødede jorden for forfattere fra Barth til Barthelme, som parodisk søgte at "rrepræsentere" tidligere litterære forsøg på repræsentation, i værker der blev karakteriseret som fabulation, surfiktion, irrealisme og metafiktion. Barth selv hyldede denne $\mathrm{g}_{\mathrm{r} y}$ ende postmodernisme i sit berømte (og ofte fejllæste) essay fra 1967, "The Literature of Exhaustion."

Der gik ikke lang tid før klagerne begyndte at dukke op, og ofte nedkaldte de - som John Gardner i On Moral Fiction (1978) en pest over både modernismens og postmodernismens huse. Gardner begræder, hvad han i en typisk bidende vending kaider den nye litteraturs kæphøje kynisme. En anden kritiker var Charles Newman, som i The Post-Modern Aura (1985) beklagede sig over dens påståede nihilisme. Slagets linjer blev trukket op: på den ene side kunstnere, der var villige til at tage fat i verdens virkelige fordringer, på den anden side kunstnere som kun var engageret i et endeløst, navlebeskuende, tekstuelt spil.

I dette korte essay har jeg ikke i sinde at påstå, at moderne litteratur er genstand for en slags storstilet meconnaissance, men jeg vil dog gerne påpege en grundliggende misforståelse blandt dem, der foretager en opdeling som den ovenfor skitserede. Den simple kendsgerning er, at relativt få af de amerikanske postmodernister rent faktisk tager afstand fra moralske og sociale 
spørgsmål. Hvor dygtige udøvere af den opdukkende æstetik de end måtte. være, så forbliver de påfaldende moralske - endog moraliserende - i deres udsyn. Hvor forbundne de end er til signifiantens frie spil, så kritiserer de vedvarende det selvsamme simulakrum, som de angiveligt udnytter. Således har Heller i Catch-22 (1961) nogle yderst alvorlige ting at sige om krig. Hver-: ken Doctorow, i The Book af Daniel (1971), eller Coover, i The Public Burning (1977), er uanfægtede af Rosenbergfamiliens i højeste grad virkelige kvaler. Abish, i How German Is It (1980), nægter at lade nazismens ondskab forsvinde ind i en form for moralsk relativisme. I roman efter roman beklager Vonnegut temmeligt lidenskabeligt vold, racisme og økonomisk udbytning. Selv Nabokov, hvis hermetiske værker giver adgang til så lidt af den sociale virkelighed (uanset hvor mange moteller han beskriver i Lolita), lader aldrig muligheden for at forhåne totalitarisme og brutalitet i både deres imaginære og virkelige former former gå fra sig.

Denne paradoksale subversion af det postmoderne evangelium er måske mest synlig i Thomas Pynchons forfatterskab. Forfatteren af Gravity's Rainbow efterlader ikke sine læsere i tvivl om sin holdning til racisme, undertrykkende økonomiske fremgangsmåder, folkedrab,- svindel i magtens korridorer og politibrutalitet. På talrige måder udtrykker han sin dybe medfølelse med, hvad han kalder de udstødte, de udeladte, de forbigåede i enhver form for udvælgelse (åndelig, økonomisk, racemæssig og kulturel). Disse er den Amerikanske Drøms søvnløse, „de fattige, de besejrede, de kriminelle, de desperate" (35), som han kalder dem i sin reportage om Watts i efterdønnigerne af optøjerne i 1965. Læserne kan spore forfatterens sympati for denne gruppe (og for den sags skyld hans foragt for de selvtilfredse udvalgte) til det årti, der omdefinerede amerikansk politisk idealisme. For at finde en slags moralsk prøvesten inden for Pynchons oeuvre behøver man blot at kaste et blik på fortællingen "The Secret Integration" (1964), hvor nogle børn forholder sig til de voksnes racefordomme ved at antage en imaginær, sort legekammerat. I et typisk udslag af, hvad der tidligere blev kaldt "black humor", gør Pynchon et af børnene til medlem i Anonyme Alkoholikere, men da en lokal afdeling af denne organisation besvarer en hen- • 
vendelse fra en alkoholiseret musiker ved at sende det ungdommelige medlem ud til ham, opdager drengen og hans ledsagere at de uforvarende er blevet redskaber i en ondskabsfuld spøg sort humor af en mere radikal slags. Musikerens, en "negers", vrede, frustration og krænkelse afslører racismens følelsesmæssige og moralske pris for børnene. Og hvad der er endnu værre, de opdager racismens evne til at inkludere dem uden de lægger mærke til det.

Pynchons romaner og andre noveller løber i planetære baner omkring tressernes sol-lignende intensitet. En stor del af forfatterskabet bebor eller favner i virkeligheden dette årti. $V$., der foregår midt i halvtredserne, blev udgivet i 1963, året hvor Kennedy blev myrdet. The Crying af Lot 49 forgår i 1964 og blev udgivet i 1966. Den centrale person i Vineland (1990) rekonstruerer et 60 'er-filmkollektivs historie; et kollektiv ledet af den mor, der forlod hende. Og endelig blev slaveriet og folkedrabets rødder, der optager forfatteren i Mason \& Dixon (1997), genstand for den offentlige bevågenhed i tresserne - som et direkte resultat af de sår, der blev genåbnet i det årti.

En videre overvejelse af tressernes centrale rolle i Pynchon-kanonen kunne begynde med et værk, der ikke synes at passe ind i det mønster, som bliver læst ud her. Gravity's Rainbow (Pynchons tredje roman), udgivet blot tre år inde i det nye årti, ignorerer ikke de år, den antageligt blev skrevet i. Her transformerer Pynchon tressernes counterculture til the Counterforce, som han forestiller sig bliver dannet i slutningen af 2. Verdenskrig. Selvom den foregår i perioden lige før og lige efter slutningen a f krigen, bevæger Gravity's Rainbow sig mod et nøje overvejet brud på sin omhyggeligt konstruerede tidslige ramme. Efter at være begyndt med en ankommende V2-raket i krigstidens London (eller rettere, med lyden fra raketten, der er eksploderet nogle sekunder før romanens berømte åbningslinje: „A screaming comes across the sky"), ender den med en mere dødbringende rakets fald - et ICBM i nutidens Los Angeles. Dette varsel om atomar udslettelse finder sted under "Richard M. Zhlubbs" auspicier, en tyndt forklædt Richard M. Ni:xon, hvis præsidentperiode begyndte i 1968 og sluttede få måneder efter romanens udgivelse. 
Pynchons første roman, $V$, beskriver - i det mindste delvist de år hvor Nixon var Eisenhowers vicepræsident. $V$. er en historisk metafiktion, der udvikler sig langs to konvergerende plotlinjer - den ene synkronisk, den anden diakronisk. En fortælling placeret i nutiden (dvs. 1955-56) komplementerer og indrammer en anden fortælling, der foregår i årtierne fra 1880 til 1943 (årene for Victoria Wrens fødsel og død). En ting der ikke er blevet tilstrækkeligt fremhævet ved denne roman er, mener jeg, dens uudtalte orientering mod året 1965. Pynchon lægger vægt på at rette læserens opmærksomhed mod den to årtier lange periode - 1918 til 1939 - mellem l. Verdenskrig og den endnu større krig, der retrospektivt var århundredets vendepunkt. Med luften fyldt af . varsler om en apokalypse slutter han med den ildevarslende opstilling af militærstyrker, der fandt sted under Suez-krisen i 1956. Læsere, der i 1963 vidste, at krisen i 1956 ikke udmundede i Armageddon, har måske haft en forbigående følelse af lettelse eller - antiklimaks - indtil de tænkte på, at Suez, som Fashoda i 1898 eller Sarajevo i 1914, havde "slået gnister på jagt efter en lunte" (386). Pynchon antyder, at den virkelige dato at $\mathrm{f}_{\mathrm{r} \text { y }}$ gte var lige over den tidslige horisont i 1965 eller 1966 - når freden endnu en

, gang ville have haft, som englænderne siger, sin tyveårige halvleg.

En anden side af romanen er dens transformation af paranoia og sammensværgelser til æstetiske principper. Påvirket af Henry Adams' (det 12. Århundredes Jomfru, antikkens Venus) og Robert Graves' (den Hvide Gudinde) kultur-definerende myter, fremprojicerer Pynchon, i selve figuren V., en legemliggørelse af tidens kærlighedsaffære med blodbad, dens manglende evne til at modstå den entropiske tendens. Sammen med Herbert Stencil („århundredets mand") opdager læseren et rædselsvækkende mønster: V. hersker, som en art skytsånd, alle de steder hvor der forekommer blodsudgydelser i årene op til og efter l. Verdenskrig. Hun repræsenterer "the Big One, århundredets hovedintrige" (226) - et mytisk rationale for en tid præget af stadig større voldshandlinger. Men i modsætning til sine modernistiske læremestre, der udnytter mytens grad af universel, instinktiv sandhed, afslører Pynchon sådanne konstruktioner som kunstige, 
som blotte projektioner af menneskets desperate behov for orden, sammenhæng og forbundethed. På denne måde forventer han, at læseren skal gøre en modopdagelse: V.'s tilstedeværelse ved voldelige begivenheder er tilfældig, og volden selv er vilkårlig. Med andre ord synes Pynchons roman, som Frosts digt "Design", at konfrontere læseren med lige skrækkelige alternativer et aktivt onskabsprincip på den ene side og, på den anden side, et fuldstændigt fravær af et styrende princip. V. er ikke, som Pynchon i begyndelsen inviterer sine læsere til at tro, den fascistiske Zeitgeist. I $V$. afslører Pynchon i sidste ende intet andet end uordenens entropiske acceleration. Intet mønster lindrer vor elendighed. Ved at erkende den voksende menneskelige appetit for en umulig historisk sammenhæng, sætter Pynchon fingeren på en af tressernes store bek $_{\mathrm{y} \mathrm{m}}$ inger. Han så og kortlagde måden hvorpå venstrefløjens paranoia begyndte at kappes med en ældre, mindre fantasirig paranoia på højrefløjen (som kort parodieres i Lot 49's Peter Pinguid Society, der beskrives som værende til højre for John Birch-sammenslutningen). Halvtredserne havde været præget af en udbredt frygt for et internationalt kommunistisk komplot, der skulle udgå fra påståede "masters of deceit", som J. Edgar Hoover kalder dem i sin bog 1938 med samme titel (fra et senere historisk udsigtspunkt ved vi, at den sande mester i bedrag - fra at gå i dametøj til politisk afpresning - var Hoover selv). Men det var tresserne, der opdagede åen ofte mere overdådige hjemlige sammensværgelse. Mens den så Zapruderfilmen, så Jack Ruby myrde Lee Harvey Oswald, læste Warrenkommisionens rapport, og rystede på sit kollektive hovede over drabene på Malcolm X, Martin Luther King og Robert Kennedy, begyndte den amerikanske offentlighed- som Oedipa Maas i The Crying of Lot 49 - at få mistanke om at "det hele er et komplot, et udførligt....... komplot"(31). I starten af det næste årti bidrog film som The Parallax View (1974) og Three Days of the .Condor (1975) ikke lige frem til at mane denne forestilling i jorden.

Pynchon undersøger ligeledes denne atmosfære af paranoia og mistro i Vineland. Her, som i $V$., udfolder han to parallelle historiske fortællinger - den ene i Ronald Reagans 1984 (ikke så forskelligt fra Orwells, lader Pynchon ane), den anden i de sene 
tressere, hvor en hel modkultur projiceres ind i "the People's Republic of Rock and Roll", en udbryderenklave på Californiens kyst. I Vineland overvejer og omdanner Pynchon den skæbne, der er blevet en generation af hippier, aktivister og revolutionære aspiranter til del - en generation der, som enhver anden, er underlagt det at vokse op og bebrejde sig selv for medskyldighed $i$ alt det, den havde foragtet og kæmpet imod. For at give denne overgang dramatisk pågåenhed strukturerer Pynchon romanen omkring et politisk drab - det perfekte emblem på et rasende årti og den tilsyneladende mystiske spredning af dets unikke energi. I romanens vigtigste scene myrdes den karismatiske Weed Atman af fæller, .der er blevet manipuleret af en agent provocateur. Derefter - uden modet til at gnave sin egen fod af - sygner en generation hen i den senkapitalistiske fælde.

Det er imidlertid med The Crying of Lot 49 at Pynchon giver os sin bedste tresserroman, fordi han her indser (med den Emily Dickinson han citerer i Gravity's Rainbow) at "succes ligger i omveje". Lige som 2 Verdenskrig kun figurerer yderst sparsomt i V og Gravity's Rainbow, synes tressernes eksplosive sociale situation i Amerika i begyndelsen at være meget tangential til den quest, som Oedipa Maas foretager. Pynchon udtrykker sin opfattelse af det historiske øjeblik gennem en række underspillede allusioner - til faktiske TV-programmer som Perry Mason og Bonanza, til imaginære popgrupper som "the Paranoids" og "Sick Dick and the Volkswagens", og til studenteraktivismen på Berkeley-universitetet. Den læser, der søger efter mere, opdager det i en stærk metafor: Trystero. Med en 400-årig tradition for postbedrageri er Trystero den illegale posttjeneste, som Oedipa Maas opdager (eller hallucinerer). Oedipa opdager også den enorme gruppe udstødte, som Trystero indoptager: en skare af hidtil ubemærkede, nogle gange alarmerende, ofte yderst patetiske elementer, der drypper malurt i Amerikas bæger. Som så mange gjorde i de dage, begynder hun som billedet på en hvid, middelklasse, lettere neurotisk forstadsselvtilfredshed. Hun kalder endda sig selv for en "Ung Republikaner" (76). Hun ender med at være gennemsyret af paranoia og kvalt af ${ }_{11}$ den mangel på overraskelser i livet, der plager hver eneste amerikaner, du ken- 
der" (170). De passager, hvor Oedipa strejfer Amerikas menneskelige elendighed, er derfor blandt de vigtigste i bogen - som i de korte glimt (givet af )lendes mand Muchos beretninger om klientellet i den brugtvognsforretning, hvor han tidligere arbejdede) af den "fortvivlelsens salat" (14), der fejes ud under sæderne og graves ud af indtrækket af de elendige biler, som fattige mennesker har indleveret.

Noget, der taler lige så stærkt for min påstand om .Pynchons argumentation via omveje og underdrivelser, er romanens eneste intense blik på de amerikanske universiteters eksploderende protester. Da Oedipa aflægger en kort visit på Berkeley, epicentret for tressernes studenteraktivisme i Amerika, accelererer Pynchons prosa gradvist mod en Ginsbergsk supernova:

Det var sommer, hverdag og midt på eftermiddagen; det var ikke et tidspunkt, hvor man skulle forvente at noget universitet, Oedipa nogen sinde havde hørt om, myldrede med folk, men det gjorde det her. Hun kom gående ned ad bakken fra Wheeler Hall og gennem Sather-porten ind på en plads, der var fuld af fløjlsbukser, cowboybukser, bare ben, lyst hår, hornbriller, cykelstativer i sollyset, mapper, vaklende borde, lange sedler for underskriftsindsamlinger, der hang ned til jorden, plakater for kryptiske FSM' er, YAF' er og VDC'er, sulfoskum i springvandsbassinet, studenter der stod og diskuterede med næsen mod hinanden. Hun bevægede sig igennem mylderet med sin tykke bog, fascineret, usikker, en fremmed, der gerne ville føle sig hjemme, men var klar over, hvor meget hun skulle gennemsøge forskellige universiteter for at finde et sted, hvor det kunne lykkes. For hun havde selv studeret på et tidspunkt, da ikke kun hendes medstuderende, men også det meste af den synlige magtstruktur rundt om og foran dem, var grebet af nervøsitet, hykleri og tilbagetrukkenhed; det var det landsomfattende svar på en vis sygelighed blandt de magthavende, som kun døden havde kunnet helbrede, og dette Berkeley mindede ikke spor om hendes egen fortids søvnige Siwash, men snarere om disse fjernøstlige eller latinamerikanske universiteter, som man læser om, disse autonome kulturcentre, hvor der udtrykkes tvivl om selv den højest elskede folklore, disse universiteter hvor den udtalte kritik virker katastrofal, hvor de valgte tilhørsforhold virker selvmorderiske - den slags universiteter, der omstyrter regeringer. Men det var engelsk, hun hørte, mens hun gik over Bancroftvejen midt mellem lyshårede børn og de mumlende Hondaer og Suzukier; amerikansk engelsk. Hvor var ministrene James og Foster og senatoren Joseph- disse kære, halvskøre tåber, der så moderligt havde overvåget Oedipas mådeholdne ungdom? I en anden verden. Ned ad et andet 
spor, en række beslutninger var taget, skiftespor lukket, de ansigtsløse sporskiftere, der havde kastet dem af sporet, var nu alle blevet forflyttet, havde deserteret, var i vildt oprør, flygtede fra dem der ville efterspore sagerne, de var gået fra forstanden, redet bort, blevet alkoholikere, fanatikere, som skjulte sig under dæknavne, var døde, umulige nogen sinde at genfinde. Det var lykkedes dem at gøre Oedipa til et yderst sjældent væsen, der måske ikke egnede sig til protestmarcher og demonstrationer, men som var simpelt hen et geni til at efterspore mærkelige ord i jakobinske tekster (103-4).

Men hvis åndrigheden i Lot 49's parodi på en hævntragedie er nogen indikator, så er den person, der er mest på hjemmebane i jakobinske tekster, Oedipas skaber, og i denne og andre passager tilbyder han et glimt af sig selv, hvorved han antyder, at The Crying af Lot 49 er en art forblommet, åndelig selvbiografi. Hvis romanens nutid er 1964 (på et tidspunkt spekulerer Oedipa og Jesus Arrabal på, om en nylig ankommet avis, date et 1904, har været i posten i 60 år), og hvis Oedipa vil være femogtredive, når . det uheld, der følger af et knust spejl, ender, så må hun være 27 eller 28 år gammel. Pynchon, som er født i 1937, var selv 27 i 1964. Oedipa er tydeligvis kandidat fra Cornell - det samme universitet Pynchon tog eksamen fra i 1959. Hun bor i Californien, og Pynchon menes at have boet i den stat- måske i det Kinneret-lignende Monterrey - fra tid til anden i årene efter udgivelsen af $\mathrm{V}$ Endelig har Oedipa rejst til Mexico, hvilket Pynchon også må have gjort, for i de år kunne kendskabet til den mexikanske maler Remedios Varo kun være blevet erhverveti selve landet:

I sin hovedperson indprojicerer Pynchon altså sin egen vrede over den amerikanske fornægtelse af mangfoldighed. Gennem hende bebor han og deltager i et amerikansk socialt og kulturelt øjeblik af enorm vigtighed. Det var trods alt i tresserne a amerikanerne for første gang opdagede, at der var sult i deres land. Det var tresserne, der bragte racediskriminationen helt ind på den amerikanske lystavle; først gennem borgerrettighedsbevægelsen og så gennem adskillige lange varme somre, under hvilke den ene by efter den anden i de centrale stater blev sat i brand. I tresserne opdagede Amerika også, at uanset hvor mange bomber dets B-52' ere kunne aflevere, så var der et vist land i Sydøstasien, 
som ville insistere på at gå sine egne veje. Og endelig var det $\mathrm{i}$ tresserne at hele nationen begyndte at indse, at den version af Amerika, man kunne se i film og på Tv, i reklamer og endog i dets egne nabolag, var sørgeligt urepræsentativ. Landet opdagede kort sagt at ikke alle dets borgere var hvide og velhavende.

I og med at Oedipa Maas er en af de litterære figurer, der giver deres historiske øjeblik udtryk, minder hun om Updikes Rabbit Angstrom eller den mere sentimentaliserede Forrest Gump. Sådanne figurer er ofte passive - deres funktion er blot at registrere eller afspejle tidsånden og dens karakteristiske kræfter. Et forsonende træk ved Zemeckis-filmen er dog dens satiriske påpegning af, at ønskerne og bevidstheden hos den generation, der repræsenteres af hovedpersonen, sjældent hæver sig op til en egentlig villen, hvor fumlende sød generationen end er. Man opdager, at drivkraften bag den nyere historie er at finde i de mindst velovervejede drifter hos den generation, som klodset snubler frem mod myndighedsalderen. På den anden side skildrer Updike i sine fire bøger om Rabbit Angstrom i fyndig detaljerigdom bevægelserne i fire på hinanden følgende årtier. I Rabbit Redux (1971), det andet bind i tetralogien, identificerer han de sene tresseres fremherskende stemning som en slags nationalt hysteri. Men Updike er loyal over for den sociale realisme, og denne roman kan synes fjern fra sit historiske øjebliks fundamentale karakter. Pynchons medkronikørs dokumentariske evner efterlader sandsynligvis læseren sulten efter andet og mere. I Oedipa, som i disse andre figurer, genkender man en moderne, demokratiseret version af en ældgammel historie: den mystiske konge hvis helbred afspejles i hans riges fysiske og åndelige tilstand. Pynchons heltindes underlige navn inviterer læserne til at se hende som en tresserversion af den Sofokleske protagonist, der foretager en quest, som berører hans egen fortid og en syg social nutid. Amerika er, som Theben, udsat for plager - en pest af racisme, økonomisk marginalisering og generel nervesvækkelse. Ved at gennemspille Oedipus' lidelser, opdager Pynchons hovedperson kilden til sit lands problemer i sig selv, i sin egen blindhed og selvtilstrækkelighed. 
Selv om de er smertefulde, så er sådanne opdagelser en del af en nations opvækst. Vi overgiver vores uskyldighed (så farlig for os selv og andre) og begynder at komme ind på livet af den sociale virkelighed i et land, der er grundlagt på en vision om lighed og retfærdighed. „,Oedipa havde hørt alt om udelukkede midter; det var noget lort, noget man skulle undgå; og hvordan kunne det nogensinde være sket her, hvor mulighederne for mangfoldighed engang var så gode?" (181). Men vildfarelsen i centrum af den amerikanske syllogisme indbyder til en kreativ dekonstruktion, for den fremstiller også det ikke-altid-genkendte positive element $\mathrm{i}$ en fortælling, der konfronterer sine egne læsere med deres eget Oedipa-agtige behov for enten at organisere verden omkring sig, at spinde eller væve eller brodere den i sine egne mentale tårne - eller at forsøge at leve $\mathrm{i}$ en verden hvor, som Pynchon siger i Gravity's Rainbow, „,intet er forbundet med noget som helst, en tilstand ingen af os kan klare særlig længe" (434). På de sidste stærke sider af Lot 49' skildrer Pynchon en Oedipa, der prøver at forholde sig til uforenelige alternativer: "Enten Oedipa midt i et virkeligt forfølgelsesvanvids hvirvlende ekstase, eller en virkelig Tristero" (182). Men med den suggestive metafor om den udelukkede midte antyder forfatteren - i 1966, lige som Jacques Derrida holdt et nu berømt foredrag i Baltimore - at enten/eller-tænkning har en tilbøjelighed til at afsløre epistemiske fælder, at uforenelige binariteter altid er hierarkiske og altid indbyder til dekonstruktion.

Lot 49 indvarsler en æra af social dekonstruktion. Dette er ikke en simpel, nihilistisk dekonstruktion, selv om det ofte betragtes sådan. Det er snarere en vej ud af Eisenhower-periodens selvtilstrækkelighed og indgangsportalen til et endeløst kreativt frit fald. Pynchon skulle senere, i Vineland, antyde, at rigiditeten påny ville gøre sig gældende i firserne; og uden tvivl ville han nu ryste på hovedet af den første Baby Boom-præsident Bill Clintons klodsethed og hans bortødsling af mulighederne for at genskabe den politiske liberalismes samfundsmæssige frie spillerum. Men sammen med Jess Traverse, den gamle arbejderaktivist i Vineland, fatter Pynchon måske mod ved Emersons bekræftelse af en endelig, kosmisk standard: 
En hemmelig gengældelse retter altid op på den guddommelige retfærdighed, når denne bringes ud af ligevægt. Det er umuligt at forrykke vægtstangen. Alverdens tyranner og fabriksherrer og monopolister kan forgæves stemme skulderen imod. Den tunge ækvator finder altid tilbage til sin ligevægt, og mennesket såvel som støvgran, stjerner og sole, må indrette sig efter den, hvis de ikke vil tilintetgøres af tilbageslaget (369).

En besynderlig moralisme når alt kommer til alt - en modvægt til alt legeriet, til de tekstuelle spilopper. Der er patos her, men ingen ironi.

Hvad skal man konkludere? Man kan ofte bedømme litterær kunst på den nøjagtighed hvormed den registrerer og vurderer sit kulturelle øjeblik. Men kunstnere skal også være racens antenner, for at parafrasere Ezra Pound, og derfor forventer vi ikke blot en samvittighedsfuld skildring af øjeblikket, men også en antydning af, hvor det øjeblik kan føre hen, og hvad det med tiden kommer til at betyde. Med andre ord forventer man af litteraturen, at den reflekterer over nutiden på måder, der vil vise sig at være mere eller mindre fremsynede. Noget overraskende er det netop denne profetiske dimension, der præger irreal, metafiktiv, postmodernistisk fiktion. Hvad der ved første øjekast blot synes at være en desperat form for fornyelse (en reaktion, i Barths formulering, på udmattelsen af litterære former) viser sig at være udtryk for tiden og dens formative ånd. I tresserne især fandt visse kulturelle fænomener - decentreringen af gamle subjektiviteter, forkortelsen af den historiske horisont på grund af film og TV - deres mest effektive repræsentation i en kunst, der problematiserede objektivitet, satte repræsentationsprocesserne i forgrunden og udtrykte den mærkelige ide, at virkeligheden aldrig var givet på forhånd, aldrig var noget man kunne adskille fra det sprog, som foregav at gengive den.

Jeg har hævdet, at Thomas Pynchon tidligt viste sig at være en særligt god kunstnerisk antenne. Han er mere fremsynet end selv sine dygtigste samtidige (og som Woolfs Lily Briscoe siger, afstand er alt). I $V$. og Gravity's Rainbow kortlægger han med stor fremsynethed prisen for Vestens Paustiske appetit efter viden og 
magt. I Mason \& Dixon udforsker han øjeblikket for nationens grundlæggelse sidst i 1700-tallet. I Vineland, i trykken da Muren faldt, flytter hans forestillingskraft sig til de post-apokalyptiske fuldb $_{\mathrm{y} r}$ delser, der kan følge en generations kommen overens med sine egne mangfoldige forræderier her i slutningen af årtusindet. Endelig skildrer han i Lot 49, som i alle sine romaner, en hel generations overgang - en arketypisk og amerikansk overgang - fra uskyld til erfaring. Det er blevet fashionabelt at nikke sammenbidt til udtalelser som Bill Grays, romanforfatteren i DeLillos Mao II , som siger at den litterære kunstner sidst i det tyvende århundrede ikke længere kan "ændre en kulturs indre liv" (41), men jeg forundres over den skarpsindighed med hvilken Thomas Pynchon snart optegner, snart foregriber en nations kringlede veje mod modenhed, dens aflæggelse af det barnagtige.

På dansk ved Tore Rye Andersen 


\section{Litteratur}

DeLillo, Don: Mao II. London; Jonathan Cape, 1991.

Eliot, Thomas Stearns: Four Quartets. New York; Harcourt, Brace and Company, 1943.

Enck, John: „John Hawkes: An Interview." Wisconsin Studies in Contemporary Literature 6 (Summer 1965), 141-155.

Gardner, John: On Moral Fiction. New York; Basic Books, 1978.

-Lyotard, Jean-Francois: The Postmodern Condition: A Report on Knowledge.

Oversat af Geoff Bennington og Brian Massumi. Minneapolis; Univ. Of Minnesota Press, 1984.

McHale, Brian: Postmodernist Fiction. New York; Methuen, 1987.

Nabokov, Vladimir: The Real Life of Sebastian Knight. London; Weidenfeld and Nicholson, 1941.

Newman, Charles: The Post-Modern Aura: The Aet of Fiction in an Age of Inflation. Evanston, Illionois; Northwestern University Press, 1985.

Pynchon, Thomas: The Crying of Lot 49. Philadelphia; Lippincott, 1966.

Gravity's Rainbow. New York; Viking, 1973.

"A Journey Into the Mind of Watts." New York Times Magazine, 12 June 1966. 34-35, 78, 80-82, 84.

Mason \& Dixon. New York; Henry Holt, 1997.

„The Secret Integration." In Slow Learner: Early Stories. Boston; Little, Brown; 1984. 139-193.

V: London; Jonathan Cape, 1963.

Vineland. Boston; Little, Brown, 1990.

O.a.: I visse af de længere citater i teksten har jeg benyttet mig af de danske udgaver af Lot 49 og Vineland (hhv. Katalognummer 49 udbydes; Gyldendal, 1968, oversat af Arne Herløv Petersen; og Vinland; Tiderne Skifter, 1993, oversat af Claus Bech). Sidehenvisningerne i teksten er dog fortsat til de mere tilgængelige amerikanske udgaver fra ovenstående litteraturliste. 